\title{
Implementation of Fraudulent Sellers Detection System of Online Marketplaces using Machine Learning Techniques
}

\author{
Pooja Tyagi, Anurag Sharma
}

\begin{abstract}
The E-commerce proportion in global retail expenditure has been steadily increasing over the years showing an obvious shift from brick and mortar to retail clicks. To analyze the exact problem of building an interactive models for the identification of auction fraud in the entry of data into $e$ commerce. This is why the most popular site's business develops with retailers and other auction customers. Where viral customers purchase products from online trading, customers may worry about fraudulent actions to get unlawful benefits from honest parties. Proactive modesty systems for detecting fraud are thus a necessary practice to prevent such illegal activities. The shopping product is built according to the customer's requirements and is safer online and resting, and the rules and regulations that are necessary to follow no longer seem to be the best of workable selection, coefficient limits that facilitate the shopping product and make it easier for the user model to compete on each platform so that it can experiment.
\end{abstract}

Keywords: Online Marketplace, Fraud Detection, Machine Learning, Support Vector Machines.

\section{INTRODUCTION}

$\mathrm{N}_{\text {ew }}$ global competing factors, more information available, educated customers, changed relationships, fast developments and more complex products are changing the corporate world into the e-economy. There is no untouched industry. In today's customer-driven market, SVM has become a critical competitive advantage. However, I have taken the challenge of developing a synchronized supply chain that may compete in the future e-economics, what particular skills are needed to master? The number and functionalities of business models employing corporatebound information systems, for example, systems connecting one or many companies with their consumers and/or suppliers, have been increased.

Manuscript received on July 19, 2021.

Revised Manuscript received on July 26, 2021.

Manuscript published on 30 July, 2021.

* Correspondence Author

Pooja Tyagi*, M.Tech, Department of Computer Science and Engineering, Dr APJ Abdul Kalam Technical University, Lucknow (U.P.), India. Email: poojatyagi0562@gmail.com

Anurag Sharma, Head, Department of Computer Science and Engineering, Dr APJ Abdul Kalam Technical University, Lucknow (U.P.), India. Email: anurag121097@gmail.com

(C) The Authors. Published by Blue Eyes Intelligence Engineering and Sciences Publication (BEIESP). This is an open access article under the CC BY-NC-ND license (http://creativecommons.org/licenses/by-nc-nd/4.0/)
New business models are emerging or existing company models are developing and renewing. But they are all Very short-lived and their profitability and function still need to be proven. Why not ask, therefore, then: what powers should the business model handle in the middle of a 'supply chain vs. supply chain competition, utilizing the internet medium? An "Electronic Marketplace B2B"' (EM) which this article describes is one of these business models [1]. Taking into account the fast growth in online transactions and electronic communications, fraud is growing and is penetrating our everyday lives at a dramatic speed. Fraud includes cybercrimes that cost hundreds of billions of dollars annually and undermines our society's security. In the current age, in which online business prevails, it is not too costly to attack the system, but it is expensive to protect the system from fraud. The breadth of fraud is huge, including credit card fraud \& financial fraud, intrusion into systems, and plagiarism to some [2].

There are many meanings of fraud; the ACFE defines "fraud" as using your occupation through deliberate abuse or exploitation of resources or assets for the personal benefit of the employer organization. The main reason for the fraud commitment is the unlawful gain on the wrong basis. This significantly affects the economy, legislation, and even the moral ideals of people. The first level of protection for technological systems against fraud is the fraud prevention system. This step aims to prevent fraud in the first instance. Mechanisms in this phase limit or delete cyber-attacks in computers (hardware and software), network, or data systems, destroy, manage, remove and prevent. The use of encryption algorithms for routing traffic is an example of this mechanism. Another mechanism is a firewall, which blocks the internal Network and networks outside. It not only helps safeguard systems from unwanted access but also allows an organization to impose a traffic safety policy between its network and the internet. This layer is however not necessarily powerful. Often prevention layers may be broken by fraudsters [3].

Published By:

Blue Eyes Intelligence Engineering and Sciences Publication

(C) Copyright: All rights reserved.

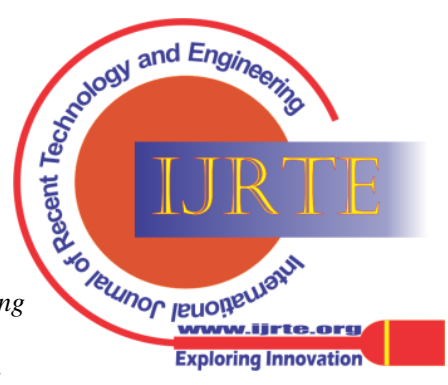




\section{REVIEW OF LITERATURE}

Surjandy [2019] The Indonesian Tax Directorate has examined the option to apply for internet buying tax. However, buying online can How about social media, generally done from the market? As social media personal functionality may be utilized for product advertising. This study will thus attempt to investigate online shopping via social media and the market. The explanatory technique for researching the customer's impact on online shopping is utilized in this study. Twenty-three key correlation factors discovered in this work were found customers in the study using the bivariate tools to describe the relationship between variables. For future online purchasing research, this early study can be used [4].

Shini Renjith [2018] The e-commerce share in global retail expenditure has been increasing steadily showing a clear shift from brick and mortar to retail clicks. The internet marketplaces have been one of the main players in this growth in recent years. The quantity and kinds of fraud that are reported in the region also grow each day, as the business model matures. Extensive analysis has been carried out and various methods to avoid and

Manage fraudulent e-commerce buyers and their transactions. A further form of Market fraud, termed merchant fraud, occurs on the seller's side. The goods/services that are advertised but never delivered at affordable prices are merely a consequence in point of such deception. This article aims to create a detection framework using machine learning methods of such fraudulent vendors. It makes the Market history data and probable fraudulent detections actions by sellers and market alerts [5].

Protocols that allow using these rather low-level protocols, common applications include mail, terminal emulation, and file transfer.

A detailed chart on how this can be used:

Renjith, Shini. (2017) The Business-to- Consumer (B2C) e-commerce market, in particular, witnesses 'tremendous survival competitors by attempting to acquire their peers' customers base and at the same time by avoiding letting current consumers churn. The E- commerce industry always has enormous amounts of customer data, including information about searches, transactions, periodic purchases, reviews submitted, feedback given, etc. Data collection and machine learning can help you analyze this huge amount of data, understand your clients' behavior, and identify possible candidates for attrition. This paper provides a support vector machine- based framework for the prediction of e-commerce client churn and a hybrid recommendation approach for customized retention activities [6].

Abdallah et al [2016] The increase in computer technology and the development of businesses have made it possible to carry out most financial transactions via electronic business systems, like credit card systems, telecommunications systems, health insurances, etc. Unfortunately, both genuine users and scammers utilize these systems. Moreover, fraudsters used various approaches to violate the systems of electronic commerce. FPSs are insufficient to offer electronic trade systems with sufficient security. The cooperation between FDS and FPSs may still be effective in protecting Systems of e- commerce. The performance of FDS, however, incorporating ideas for drifting, real-time detection, skewed delivery, huge amounts of data, etc., is hindered and challenged. The purpose of this study article is to systematically and completely describe these problems and challenges that impede the performance of FDS. Five online commerce systems have been chosen, including credit card, telecommunication, health, auto, and internet sales. The common forms of fraud are being closely introduced in e-commerce systems. Furthermore, cuttingedge FDS methods are addressed in this section in chosen ecommerce platforms. A short discussion of possible research trends and conclusions is then given shortly [7].

\section{DATA ANALYSIS AND TESTING}

\section{A. TCP/IP Stack}

TCP/IP is the world's most utilized non-proprietary security protocol because computers may connect on multiple networks using a variety of platforms for software and hardware. Protocols for both LANs and WANs work just as well. TCP/IP collection is a collection of protocols named after the Transmission Control Protocol (TCP) and Internet Protocol, the two most recognized and important protocols (IP). TCP/IP contains a variety of superior

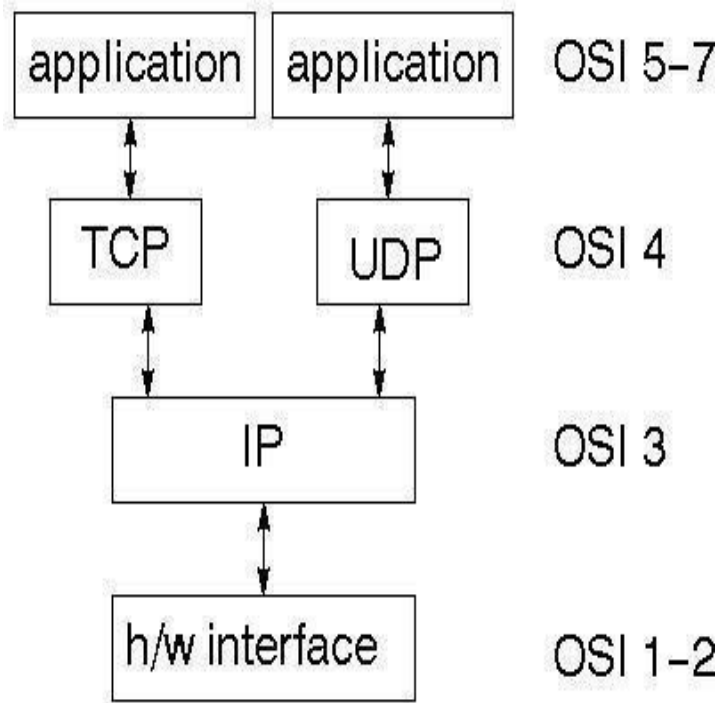

Fig.1. TCP/IP STACK. [8]

Interconnected data is utilized in several major cases for product development [9].

\section{B. IP Chart flow}

This allows us to protect the data on the computer with a null connection. Take every chart to later explain the details. Soft copies have been printed and sent to magazines so that they may be distributed to other cities. and Sciences Publication (c) Copyright: All rights reserved.
Blue Eyes Intelligence Engineering

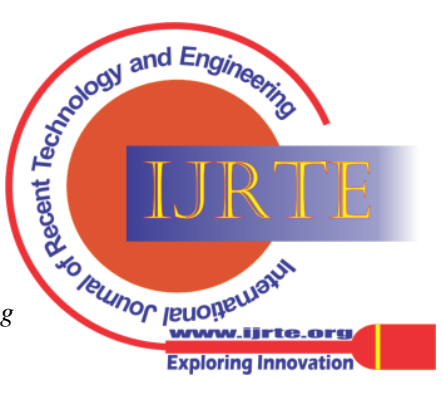




\section{UDP}

The connection to the other department will be nil. All networks of data are to be connected with the number of registered customers when sorted with many drawings and contact details. Mostly the necessary database system is gathered.

\section{TCP}

A large transport plans that gives all the other detail along with an address. Several such virtual connections are sent.

\section{E. FDS}

Large service arrangements include all the other information and locations. Various virtual links that are being transmitted, manual audit techniques like discovery sampling were utilized for the detection of fraud in earlier years.

\section{F. Online Marketplace}

An online market is a sort of e-commerce site where multiple vendors, whether brands, stores, or people, offer products and services. Customer attractions and money transactions are handled by the market owner. The vendors manage the manufacturing, packaging, and shipping. Consumers enjoy excellent online buying experiences and some of the key reasons include. More options between the varieties of products in a one place like competitive seller price. Better inventory availability since many suppliers sells the same product on the same platform, comfort and privacy of the transactions in a location that is not shared with an individual vendors.

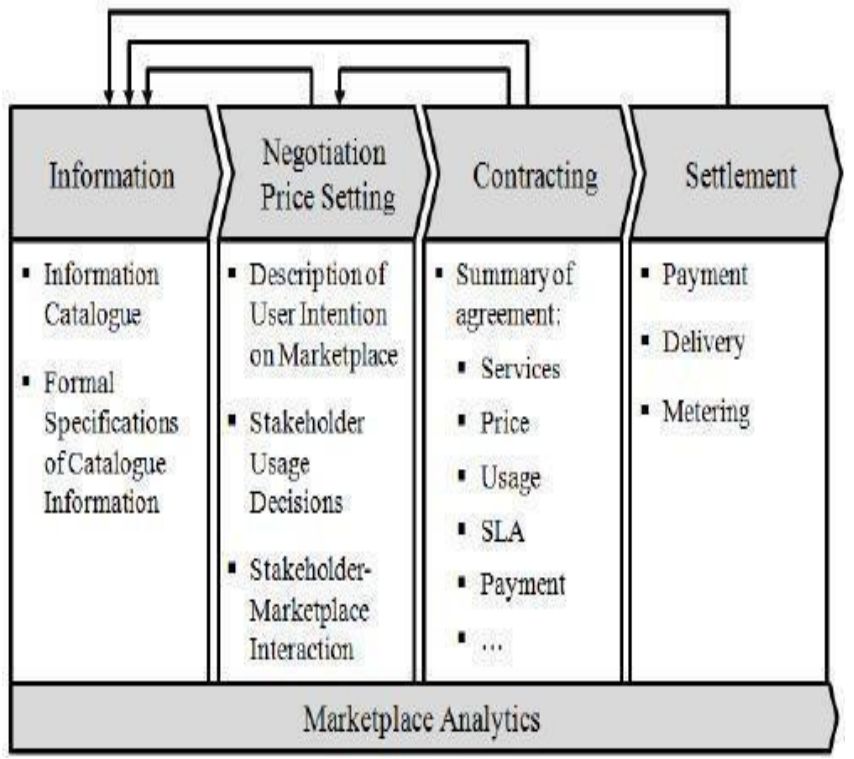

Fig. 2. Online Marketplace Operations [10].

\section{G. Machine Learning}

Machine learning is an informatics and artificial intelligence area, which is focused on computers or machines that learn from previous transactions, in the performance and experience of specific tasks. Using the supervised machine training technique, an intelligent decision-making algorithm may be developed. This technique requires some previous information known as a training set for capturing and agreeing on input and output scenarios.[11] The study algorithm leads to an iterative process that helps to anticipate the output in an entry situation when output data are not accessible. Machine learning aims to design a framework that can mechanize an uncertain situation of a refined theory.

\section{Supervised Learning}

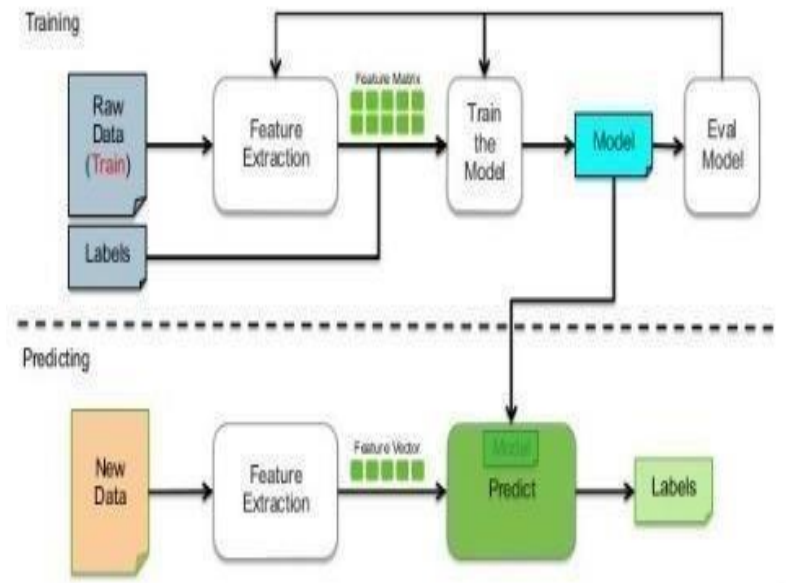

Fig. 3. Workflow of Supervised Learning Method [12].

\section{H. Support Vector Machine (SVM)}

Vector Machine Support (SVM) is a supervised model for apprenticeships. SVM and related learning algorithms are powerful instruments for various application areas for classification and regression requirements. SVM will learn from a training set in which each candidate is split into one of two classes and can build a framework that will allow every new candidate to be divided into one of the two [13]. The best vectors or choices in the functional space are determined. This is done as an algorithm for the issue of classification.

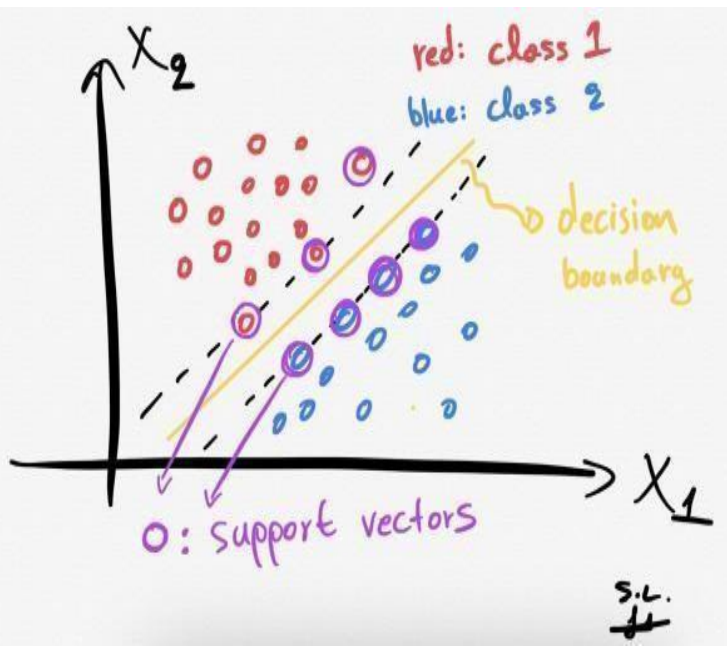

Fig. 4. Support Vector achine[14] Model Testing

Published By:

Blue Eyes Intelligence Engineering and Sciences Publication

(C) Copyright: All rights reserved.

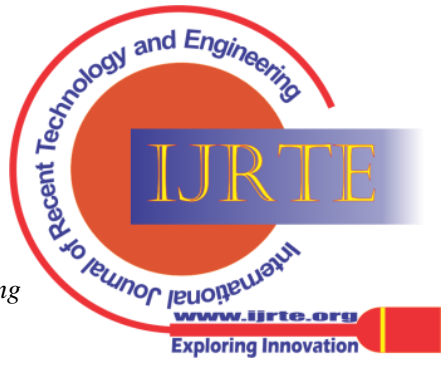


We illustrate how the page looks so that each figure is intact when the product goes live. It was suggested that any secular problem would be the ideal time. At times, products that may be also used for testing are extremely delicate and sensitive.

\section{TYPES OF TESTS}

1. System Correction

2. White Box Testing

3. Black Box Testing

4. Unit Testing

5. Integration Testing

\section{RESULTS ANALYSIS AND IMPLEMENTATION}

Implementation is a process in which many things have to be followed and understood, and if necessary provide some additional benefits. Politically correcting is also one reason why the rest of the team may be examined and serviced by small additions.

Every time a record is created, the product was best produced and its concentration has kept it ready since that happened. To reach the next level is always the best sense to try and fix all the mistakes so it doesn't have any pain.

This article presents a basic basis for defining and dealing with an online marketplace to fraudulent sellers using a machine learning technique, particularly in exploiting the SVM's ability to grad. This is a multi-step strategy: the collection of all accessible market information, Data extraction, SVM Training and the discovery and categorization of fraud and finally a fraud management module.

Table I: Test Case Analysis

\begin{tabular}{|c|c|c|c|c|}
\hline $\begin{array}{c}\text { Test } \\
\text { Case } \\
\text { ID }\end{array}$ & Description & $\begin{array}{l}\text { Expected } \\
\text { outcome }\end{array}$ & $\begin{array}{c}\text { Actual } \\
\text { outcome }\end{array}$ & $\begin{array}{c}\text { Status } \\
\text { (Pass/Fail) }\end{array}$ \\
\hline 1 & $\begin{array}{l}\text { Type } \\
\text { Wrong } \\
\text { User name } \\
\text { and } \\
\text { Password } \\
\text { for any } \\
\text { user. }\end{array}$ & $\begin{array}{c}\text { An Error } \\
\text { message has } \\
\text { to be } \\
\text { displayed. It } \\
\text { should prompt } \\
\text { for a } \\
\text { password. }\end{array}$ & $\begin{array}{l}\text { An error } \\
\text { message is } \\
\text { displayed } \\
\text { prompting the } \\
\text { wrong } \\
\text { password. }\end{array}$ & $\mathrm{P}$ \\
\hline 2 & $\begin{array}{l}\text { ID and } \\
\text { Password } \\
\text { is the } \\
\text { Priority. }\end{array}$ & Website pages. & $\begin{array}{l}\text { The home } \\
\text { page is } \\
\text { displayed. }\end{array}$ & $\mathrm{P}$ \\
\hline 3 & $\begin{array}{l}\text { Any field } \\
\text { as regards } \\
\text { to } \\
\text { product } \\
\text { adding is } \\
\text { not } \\
\text { given. }\end{array}$ & $\begin{array}{l}\text { Should } \\
\text { prompt for } \\
\text { that specific } \\
\text { field. }\end{array}$ & $\begin{array}{l}\text { Prompting for } \\
\text { the empty field }\end{array}$ & $\mathrm{P}$ \\
\hline 4 & $\begin{array}{l}\text { Any field } \\
\text { left blank } \\
\text { during } \\
\text { registration }\end{array}$ & $\begin{array}{l}\text { Should } \\
\text { prompt for } \\
\text { completion } \\
\text { of } \\
\text { Registration. }\end{array}$ & $\begin{array}{l}\text { Prompting to } \\
\text { enter the } \\
\text { specific field. }\end{array}$ & $\mathrm{P}$ \\
\hline
\end{tabular}

\begin{tabular}{|c|c|c|c|c|}
\hline 5 & $\begin{array}{l}\text { Click } \\
\text { logout }\end{array}$ & $\begin{array}{c}\text { Should come } \\
\text { to the Main } \\
\text { page. }\end{array}$ & $\begin{array}{l}\text { The main page } \\
\text { is displayed if } \\
\text { log out is } \\
\text { clicked. }\end{array}$ & $\mathrm{P}$ \\
\hline 6 & $\begin{array}{l}\text { Verification } \\
\text { of admin } \\
\text { name and } \\
\text { password. }\end{array}$ & $\begin{array}{l}\text { In the Correct } \\
\text { owner name, } \\
\text { password, the } \\
\text { system } \\
\text { should not } \\
\text { log in. }\end{array}$ & $\begin{array}{l}\text { The system } \\
\text { did not log in. }\end{array}$ & $\mathrm{P}$ \\
\hline 7 & $\begin{array}{l}\text { Verification } \\
\text { of Seller } \\
\text { name and } \\
\text { password. }\end{array}$ & $\begin{array}{l}\text { In Correct } \\
\text { Seller } \\
\text { name, } \\
\text { Incorrect } \\
\text { password, } \\
\text { the system } \\
\text { should not } \\
\text { log in. }\end{array}$ & $\begin{array}{l}\text { The system } \\
\text { did not log in. }\end{array}$ & $\mathrm{P}$ \\
\hline \multirow[t]{2}{*}{8} & $\begin{array}{l}\text { Verification } \\
\text { of Seller } \\
\text { uploads the } \\
\text { products }\end{array}$ & $\begin{array}{l}\text { Incorrect } \\
\text { product } \\
\text { name, } \\
\text { product } \\
\text { image, } \\
\text { product } \\
\end{array}$ & $\begin{array}{c}\text { The product did } \\
\text { not upload. }\end{array}$ & $\mathrm{P}$ \\
\hline & $\begin{array}{c}\text { in the } \\
\text { application. }\end{array}$ & $\begin{array}{c}\text { Descripti } \\
\text { on and } \\
\text { offer } \\
\text { price. }\end{array}$ & & \\
\hline 9 & $\begin{array}{l}\text { Verification } \\
\text { of } \\
\text { r use } \\
\text { Purchase the } \\
\text { Products. }\end{array}$ & $\begin{array}{l}\text { Users can } \\
\text { Select the } \\
\text { product } \\
\text { And } \\
\text { based On } \\
\text { offers } \\
\text { they can } \\
\text { purchase } \\
\text { the } \\
\text { product. }\end{array}$ & $\begin{array}{c}\text { The user can } \\
\text { able to purchase } \\
\text { the product and } \\
\text { the Product is } \\
\text { maintained in } \\
\text { the shopping } \\
\text { cart. }\end{array}$ & $\mathrm{P}$ \\
\hline 11 & $\begin{array}{l}\text { Verification } \\
\text { of admin } \\
\text { getting } \\
\text { complaint } \\
\text { Details. }\end{array}$ & $\begin{array}{l}\text { The data } \\
\text { is reading } \\
\text { from the } \\
\text { server } \\
\text { and data } \\
\text { is } \\
\text { presented } \\
\text { On the } \\
\text { Admin } \\
\text { Page. }\end{array}$ & $\begin{array}{c}\text { The data is } \\
\text { reading From } \\
\text { the server and } \\
\text { data is } \\
\text { presented on } \\
\text { the admin page, } \\
\text { once he verified } \\
\text { complaint } \\
\text { details move to } \\
\text { status to trusted } \\
\text { or Doubtful. }\end{array}$ & $\mathrm{P}$ \\
\hline 12 & $\begin{array}{l}\text { Verification } \\
\text { of admin } \\
\text { blocks the } \\
\text { Product. }\end{array}$ & $\begin{array}{l}\text { The } \\
\text { product } \\
\text { needs to } \\
\text { be } \\
\text { removed } \\
\text { from the } \\
\text { Applicati } \\
\text { on }\end{array}$ & $\begin{array}{l}\text { The product } \\
\text { was removed } \\
\text { from the } \\
\text { Application }\end{array}$ & $\mathrm{P}$ \\
\hline
\end{tabular}

Published By:

Blue Eyes Intelligence Engineering and Sciences Publication (c) Copyright: All rights reserved.

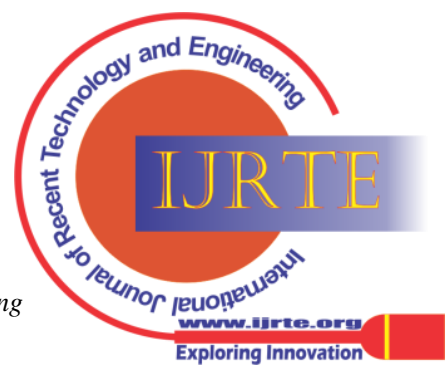




\section{CONCLUSION}

In recent years fraud instances, especially in important and sensitive technological fields have risen. So the fight for Fraud is serious. The correct protection method against fraud is fraud prevention and detection. That is not enough to prevent fraud alone. To protect vital services in technical systems,Fraud Detection is recommended. Each World Wide Web (WWW) store has been very famous and benefits everyone from its good terms, mainly as a display. Ever since the beginning, it has always been a method for customers to choose much that they would all like at the best price when they paid more attention to the customer's needs as a result, as a product was sold online or in the shop and the kind of service given. Through the budget that was set to sell itself for managing the shop, our dealers and the suppliers were in the finest relationship. Selling the products has always been a good notion for buyers to find out what they can best invest in and whether it'struly worth investing in them. The administration of all resources and the quick response to online orders always gives you a secure cause for offering your highest quality goods, products. Every development would be at no cost and recognizing that we have the pros and cons scenario; where there is also a connection established in this process in which end-users and purchasers may demonstrate the genuine nature of the products sold.

\section{REFERENCES}

1. M. Grieger, "Electronic marketplaces: A literature review and a call for supply chain management research," Eur. J. Oper. Res., 2003, doi: 10.1016/S0377-2217(02)00394-6.

2. S. Kodate, R. Chiba, S. Kimura, and N. Masuda, "Detecting problematic transactions in a consumer-to-consumer e- commerce network," Appl. Netw. Sci., 2020, doi: 10.1007/s41109-020-00330-x.

3. S. Tsang, Y. S. Koh, G. Dobbie, and S. Alam, "Detecting online auction shilling frauds using supervised learning," Expert Syst. Appl., 2014, doi: 10.1016/j.eswa.2013.10.033.

4. Surjandy, A. S. L. Lindawati, Siswantini, and E. R. Kaburuan, "Analysis of Shopping Online Influence Factor through Personal Social Media and Market Place," 2019, doi: 10.1109/SIET48054.2019.8986048.

5. S. Renjith, "Detection of Fraudulent Sellers in Online Marketplaces using Support Vector Machine Approach," Int. J. Eng. Trends Technol., 2018, doi: 10.14445/22315381/ijett- v57p210.

6. S. Renjith, "B2C E-Commerce Customer Churn Management: Churn Detection using Support Vector Machine and Personalized Retention using Hybrid Recommendations,” Int. J. Futur. Revolut. Comput. Sci. Commun. Eng., 2017.

7. Abdallah, M. A. Maarof, and A. Zainal, "Fraud detection system: A survey," Journal of Network and Computer Applications. 2016, doi: 10.1016/j.jnca.2016.04.007.

8. H. Rili, "Research and application of TCP/IP protocol in embedded system," 2011, doi: 10.1109/ICCSN.2011.6014961.

9. "MARKETPLACEMANAGEMENT."

http://websupportindia.com/marketplace-operations.

10. V. Nasteski, "An overview of the supervised machine learning methods," HORIZONS.B, 2017, doi: 10.20544/horizons.b.04.1.17.p05.

11. J. Leonel, "Supervised Learning." https://medium.com/@jorgesleonel/supervised-learningc16823b00c13.

12. S. Ghosh, A. Dasgupta, and A. Swetapadma, "A study on support vector machine based linear and non-linear pattern classification," 2019, doi: 10.1109/ISS1.2019.8908018.

\section{AUTHORS PROFILE}

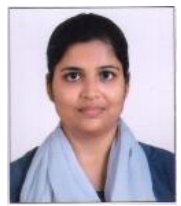

Pooja Tyagi, is currently pursuing M.Tech in Computer Science and Engineering from Faculty of Engineering and Technology, Agra College, Agra, Dr. APJ Abdul Kalam Technical University, Lucknow, India. She completed her B.Tech in 2019 in Computer Science and Engineering from Faculty of Engineering and Technology, Agra College, Agra, Dr. APJ Abdul Kalam Technical University, Lucknow, India. Her leading research is in the field of Machine Learning.

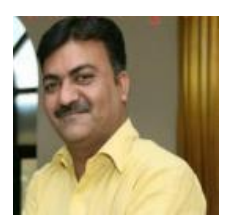

Anurag Sharma, completed his M.Tech degree in Computer Science \& Engineering from Dr. BR Ambedkar University, Agra and PhD from Bhagwant University, Ajmer, Rajasthan, India. Presently working as Head of Computer Science \& Engineering Department, at Agra College, Agra and also holding many administrative posts. Research area in the field of Wireless networking, Ad-hoc networks, Machine Learning Database etc. Total publications are around 20 papers in different national/international journals \& conferences. He attended Short term courses at IIT Guwahati and Workshops, Faculty development programs organized by different the universities and colleges also the Life member of IEI and many other societies.

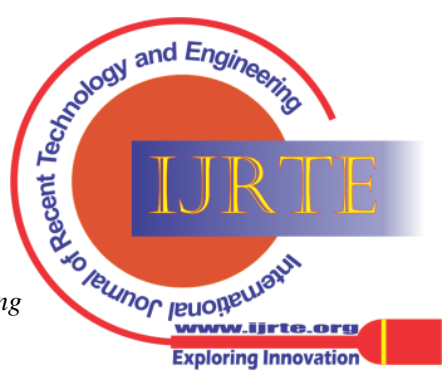

